\title{
Reimagining Safety Net Programs
}

\subsection{INTRODUCTION}

Safety nets-food and non-food based-have been the cornerstone of India's emerging social security regime. While these safety programs have existed for a while, the last 15 years have seen the emergence of a welfare policy structure in India. Driven by the rights-based initiative, which recognized basic entitlements to work, food and education as a fundamental right of the citizen, safety net programs have been enshrined in the constitution. The five main programs which provide a semblance to the social security architecture in India-Public Distribution System (PDS), Integrated Child Development Scheme (ICDS), Mid-Day Meal Scheme (MDMS), Mahatma Gandhi National Rural Employment Guarantee Scheme (MGNREGS) and pensions for widows and elderly-have played a crucial role in the reduction of poverty, increasing incomes, and reducing malnutrition. ${ }^{1}$ However, these schemes have also been heavily criticized for their design, targeting errors and corruption which leads to very high costs of operations. Other alternatives have been proposed which incorporate the benefits of technological advancements in monitoring and better targeting. Yet, the design of these safety net programs have been a continuing debate in policy circles.

\footnotetext{
${ }^{1}$ In the previous chapter, we have discussed the potential role of safety nets in reducing the triple burden of malnutrition.

(C) The Author(s) 2019

P. Pingali et al., Transforming Food Systems for a Rising India, Palgrave Studies in Agricultural Economics and Food Policy, https://doi.org/10.1007/978-3-030-14409-8_6
} 
The policy debate in India on the safety nets is grappling with the following questions. First, should the schemes be targeted towards poor or be universally applicable? Second, should the social security benefits be in the forms of in-kind transfers or the beneficiaries be handed cash of an equivalent amount to choose their consumption bundle? Third, should these social security schemes be replaced with an unconditional Universal Basic Income (UBI)? While payments for pensions or public works program are intrinsically cash based, the cash versus kind argument is most relevant for the food assistance programs like PDS and ICDS. Reading the debate closely, one gleans that much of this debate is more ideological than evidence-based. The idea of improving nutritional outcomes is only implied in these deliberations without explicit consideration to the role of safety net programs in tackling the multiple emerging nutritional challenges as seen in the previous chapter. Part of this confusion stems from the fact that the benefits and costs of safety net programs are difficult to evaluate and compare since they do not make a clear distinction between its role as income support and nutritional assistance.

Given India's regional divergent experience of structural transformation, in this chapter, we explore the ability of safety nets to create a sufficient floor for those who are disadvantaged. The challenge of a nutrition-sensitive food system lies in its ability to respond to the current nature of economic transformation and food demand. Given the pressures of urbanization, dietary transition, demographic changes, higher rural-urban mobility, establishment of newer food value chains, changing consumer preferences, ecological degradation and the processes of globalization, these changes create new challenges for food safety nets regarding delivering food safely to individuals who are disadvantaged. The rise in urban population implies greater share of net food consumers in the future who would rely on traditional as well as commercial food value chains for accessing food. This would increase competition for food safety nets which have played a role in the procurement and distribution of food. Less physically demanding jobs and better sanitation environment further reduces the number of calories needed and increases demand for diverse nutrients. Competition for land and dwindling natural resources like water influences the choice of the crop among farmers. Development of markets and connection to modern value chains provide farmers with greater avenues for growing commercial crops which further influences the food system diversity. Given these expected changes in the future, we ask the following question: how should safety nets be 
designed to ensure better nutrition outcomes? What kind of safety net programs would help to improve diets and nutritional outcomes?

To answer this question, we first examine the range of existing safety nets in India and their implications for the food system. We describe the why, how and what of the safety nets regarding their conception, their subsequent achievements and failures, and their potential future. We deliberate upon the usefulness of these programs with a keen eye on the changing nature of food demand and discuss ways to improve these programs. We argue that the policy makers should think hard on whether the same objectives which these programs intend to achieve today would stay relevant in the future too. Here, we also align the debates around poverty, consumption demand, supply considerations and how all these factors square up with the relevance of these safety nets.

\subsection{The Role of Safety Nets in the Food Systems}

The idea of social safety nets became popular in the global policy dialogues during the 1980s and 1990s as a part of the humanitarian and developmental debates (Croppenstedt, Knowles, \& Lowder, 2017). The World Development Report 1990 discussed the inclusion of safety nets as income support during periods of stress and calamities, as one of the planks of the "New Poverty Agenda". Gradually, ideas around safety nets began to use it as a lever for addressing economic shock and reduction in chronic poverty. Without a clear definition around the kind of safety nets to be pursued, it was broadly understood to be a set of interventions aimed at reducing risks and vulnerability-social and economic-to alleviate extreme poverty and deprivation. Safety nets became an essential part of the poverty eradication agenda in developing countries given the imperfections of credit and insurance market which ensures the citizens against any unanticipated income shocks. Gradually, it expanded to address specific concerns of hunger and nutrition. Greater scholarship on the disadvantages faced by women, children and the elderly further led to calls for specifically designed safety nets which ensures the well-being and agency of the most marginalized.

There are multiple other pathways through which safety nets contribute to the food system. First, through the income pathway, transfers-inkind or direct - add to household income which enables food diversification, investment in human capital and overall productivity. Greater income support potentially leads to higher investment in education and health of 
children enabling a better quality of human capital which has implications for future productivity and earning capacity. For the cultivating households, greater resources help overcome liquidity and credit constraints which influences greater investment in agriculture and livestock. It also frees up resources and creates avenues to move out of agriculture. Second, food assistance or income transfer programs ensure inter-temporal consumption smoothing and food access as livelihood options in developing countries often follow a cyclic process. Third, safety nets targeted at women or children have implications for intra-household food access. Supplementary food and nutritional assistance programs at various stages of the life cycle lead to greater reduction in enhancing human capital. In the long run, such interventions lower the probability of intergenerational poverty. Similarly, income transfers focused at women in the household enhances their economic status and bargaining power in the economy. Fourth, safety nets promote local economic growth especially when it involves agriculture. Greater productivity improves production capacity and stimulates demand for locally grown agricultural products.

As food systems evolve along the stages of economic development, so does the need, design and role of safety nets. Fiscal ability to spend on safety nets by the government also changes with economic development. Given the structural transformation of the Indian economy, this chapter deliberates upon how safety nets should be envisaged in the future anticipating economic growth, demographic transitions and technological advancement.

\subsection{Safety Net Programs in India}

India has a long history of safety net programs. These programs, however, were largely driven by policy concern such as weather shocks, price risk, social control and so on. There has not been a concerted effort at creating a social security architecture aimed at addressing the issues of poverty and vulnerability. For example, PDS was introduced during the 1940s to shield urban consumers against food shortages. A public works program was introduced in the state of Maharashtra during the early 1970s after prolonged droughts and in 1977. The Maharashtra government introduced the Employment Guarantee Act employing nearly half a million workers. ICDS, too, was initiated during the 1970s, though on a pilot basis. It was only in the last two decades that a holistic safety net design began to emerge. 
Table 6.1 Description of major safety net programs in India

\begin{tabular}{llll}
\hline & $\begin{array}{l}\text { Targeted } \\
\text { population }\end{array}$ & Nature of the program & Objectives \\
\hline PDS & $\begin{array}{l}\text { Poor } \\
\text { Children and } \\
\text { mothers }\end{array}$ & $\begin{array}{l}\text { In-kind food transfers } \\
\text { Supplemental food } \\
\text { assistance }\end{array}$ & $\begin{array}{l}\text { Hunger reduction } \\
\text { Nutritional assistance }\end{array}$ \\
MDMS & $\begin{array}{l}\text { School going } \\
\text { children }\end{array}$ & Hot cooked meals & Classroom hunger mitigation \\
MGNREGS & $\begin{array}{l}\text { Universal rural } \\
\text { population }\end{array}$ & Public works program & Rural livelihoods \\
Pensions & $\begin{array}{l}\text { Widows and } \\
\text { elderly } \\
\text { Poor }\end{array}$ & Income transfer & Poverty among elderly \\
RSBY & Health insurance & $\begin{array}{l}\text { Safeguard against health } \\
\text { shocks induced poverty }\end{array}$ \\
\hline
\end{tabular}

Recent reforms in the safety net programs coincided with the spectacular pace of economic growth and the consequent distributional concerns of growth such as lack of its "inclusiveness". Safety net expansions have provided economic security to a large section of the poorer population. The bulk of the social security expenditures comprise five major programs: PDS, ICDS, MDMS, MGNREGS and pension schemes (Drèze \& Khera, 2017). A brief description of these programs is provided in Table 6.1 in terms of its objectives, targeted population and the nature of transfer. According to a ballpark estimate by Narayanan and Gerber (2017), the central government of India spent around 1.7\% of the gross domestic product (GDP) on the combined operations on PDS, ICDS, MDMS and MGNREGA in 2013-14. ${ }^{2}$ In the last ten years, the budget outlay on these programs has increased substantially. Expenditure on ICDS has almost quadrupled from Rs. 40 billion in 2006-07 to almost Rs. 160 billion in 2016-17 (Fig. 6.1). Food subsidy and MGNREGS comprise the largest share of expenditure and have seen the greatest increase too. ${ }^{3}$ Despite huge outlays, these programs have been heavily criticized for being prone to corruption, ineffective in reaching

\footnotetext{
${ }^{2}$ Arriving at an exact estimate for these schemes is non-trivial because the outlays and expenditures on food assistance programs in government statistics also include the expenses on food procurement and stocking operations. Further, state governments may spend over and above the central government's expenditures, making the calculations imprecise.

${ }^{3}$ It must be noted that food subsidy also includes the food procurement operations. It is very difficult to get data which differentiates PDS from overall food subsidy.
} 


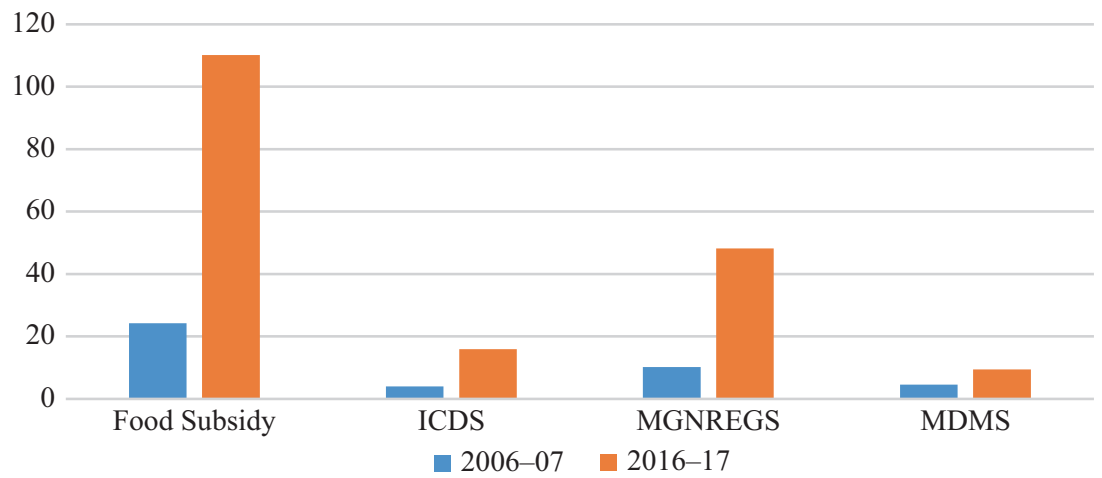

Source: Government Budget Documents

Fig. 6.1 Budget expenditures on major safety nets (in Rs. '00 billion)

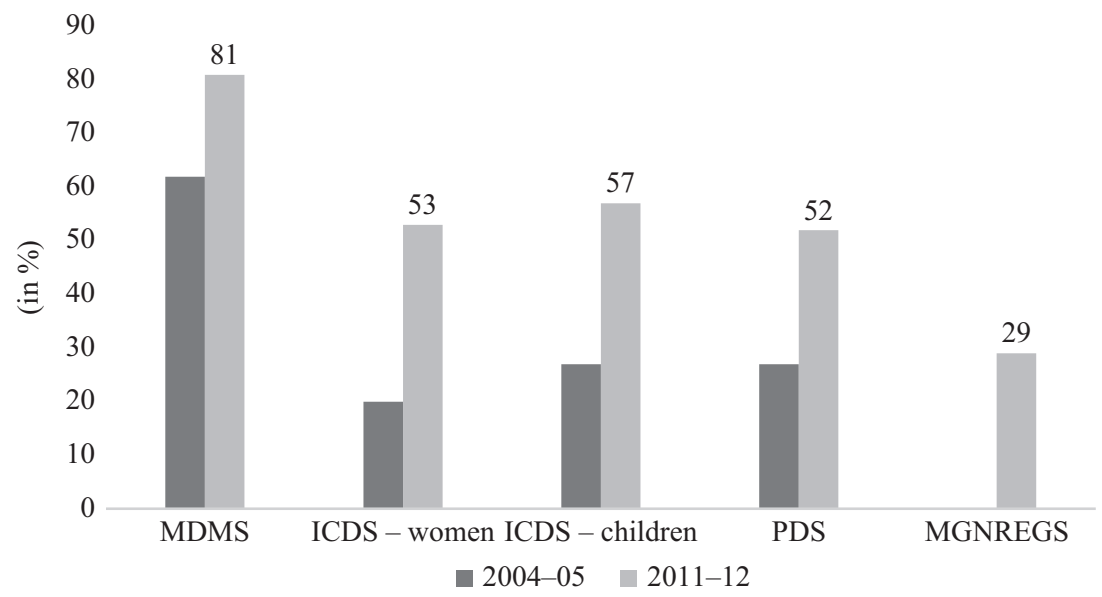

Source: All figures from MGNREGS from Drèze and Khera (2017) based upon the Indian Human Development Surveys (IHDS I and II).

MGNREGS figures are only for rural households.

Fig. 6.2 Coverage and expansion of major social safety net programs

the poor and therefore a huge fiscal drain. The last decade, however, has seen a substantial improvement in the coverage and utilization of these programs. Using longitudinal data between 2004-05 and 2011-12, Drèze and Khera (2017) highlight the extent of this expansion (Fig. 6.2). MDMS is the most popular scheme and its access among school going 
children improved from $62 \%$ in $2004-05$ to $81 \%$ in $2011-12$. Substantial improvement in the usage of ICDS and PDS are also evident.

Safety nets always wrestle with the problem of identifying the best design where the benefits are disproportionately higher to the non-poor households. At the same time, there have to be sufficient incentives for the beneficiaries to work. These challenges are further compounded among the poor and developing countries where the proportion of people requiring support remains very high compared to the fiscal resources at their disposal. Usefulness or efficacy of the social safety net has therefore been a very active policy debate in India. While it has been unanimously acknowledged that a large share of the Indian population is poor and needs some sort of support against anticipated and unanticipated economic shocks, the debate has mostly veered around what is the most efficient and economical way to build a safety net architecture. Arguments have put across, therefore, to promote growth as a poverty reduction and channel resources into more productive investments. Some have argued that social assistance should rely more on narrow targeting. There have been calls for moving towards a cash-based transfer replacing the in-kind food assistance through PDS. Of late, there has been a debate around the usefulness of a UBI to all households.

\subsection{Food-based Safety Net Programs}

With a life-cycle approach to food security, food assistance at various stages of life is provided through PDS, MDMS and ICDS. Under the umbrella of the National Food Security Act (NFSA), these programs aim at providing nutrition to nutritional assistance for pregnant and lactating mothers, infants, school going children and senior citizens. NFSA, as it was passed in the Indian parliament in 2013 states that its objective is to “... provide for food and nutritional security in human life cycle approach, by ensuring access to adequate quantity of quality food at affordable prices to people to live a life with dignity and for matters connected therewith or incidental thereto". NFSA further aims to expand the coverage of PDS to about two-thirds of India's population- $75 \%$ and $50 \%$ of the rural and urban population respectively-under PDS. Eligible monthly entitlements include $5 \mathrm{~kg}$ of grains per person at a highly subsidized prices of Rs. 3/2/1 per $\mathrm{kg}$ for rice/wheat/coarse grains. The identified poorest of the poor households, however, will continue to receive $35 \mathrm{~kg}$ of food grains per month. Other nutritional assistance include cooked meals to mothers during pregnancy and six months after 
childbirth in addition to maternity benefit of not less than Rs. 6,000 (100 USD). For children up to 14 years of age, NFSA entitles nutritious meals. In cases where entitled food grains or meals are unable to be provided, the beneficiaries are entitled to a food security allowance. We will discuss PDS, ICDS and MDMS here in detail and their relevance for food and nutritional security.

PDS was introduced as a food security mechanism during the World War period under colonial rule. The original idea being that the rural areas have greater access to food while urban residents need food provisions during times of scarcity. The PDS expanded its rural presence only in the 1970s as the Green Revolution led to food surpluses. In a bid to incentivize farmers to produce more, the government announced a minimum support price (MSP). Farmers were free to sell to the government at the MSP which remained lower than the market prices and provided a floor price. To ensure an outlet for this huge procurement operation, the government opened more rural Fair Price Shops (FPS) which led to the expansion of PDS. At the same time, inefficiencies like leakages and corruption were rampant in this procurement-stocking-distribution system, given its huge size. Initially designed as a universal scheme, PDS was curtailed to a targeted program in 1997 as India adopted a structural adjustment program to bring down the subsidies. Various state governments, in the meanwhile, continued to have a non-targeted PDS in pursuance of a more populist political regime. PDS has been criticized as being poorly designed, leaky, beset with targeting errors, corruption-prone and a drain on the fiscal capacity of the government. The most essential challenge in a targeted program is how to identify beneficiaries. India has failed abysmally when it comes to the targeting of its welfare programs for the poor (Jha \& Ramaswami, 2010; Kotwal \& Ramaswami, 2014). For various schemes, the government of India classifies households as poor and non-poor. Recent estimates provided in the Economic Survey of India 2017-18 indicate that targeting errors continue to persist (Government of India, 2018). Only $28 \%$ in the bottom $40 \%$ of the household access PDS, while $36 \%$ of the benefits accrue to the non-poor (Table 6.2).

Identification of poor is beset with conceptual and administrative challenges. The criteria for identifying poor household are often vague, and the information on those indicators are hard to collect (Hirway, 2003). At the lowest level of administration, such as villages and urban local bodies, political favoritism often leads to poor being left out of the schemes meant for them (Panda, 2015). In a targeted program like PDS, identification of 
Table 6.2 Targeting of PDS and MGNREGS (in \%)

\begin{tabular}{lcc}
\hline & PDS & MGNREGA \\
\hline $\begin{array}{l}\text { Non-beneficiaries } \\
\text { Among the beneficiaries }\end{array}$ & 40 & 65 \\
$\quad$ Leakages & 36 & 20 \\
$\quad$ Benefits to non-poor & 36 & 43 \\
$\quad$ Benefits to the bottom $40 \%$ & 28 & 37 \\
\hline
\end{tabular}

Source: Economic Survey 2017-18, p. 200, Fig. A5

beneficiaries has been the major issue. Many states-for example, Tamil Nadu, Himachal Pradesh, Chhattisgarh and parts of Odisha-have therefore made PDS entitlements universal, thereby obviating the need for targeting. These states have performed better in take-up rates and had lower leakages after universalization (Drèze, Himanshu, Khera, \& Sen, 2015). The recent expansion of the PDS has come about through an expansion of the number of beneficiaries through a more "inclusive approach" as the exclusion of the non-poor often gets less political support and suffers the risk of being sabotaged by the politically powerful non-poor groups. Despite the success of universal PDS in many states, most of the states continue having a targeted PDS. The share of targeted beneficiaries, however, is expected to expand across most of the poorer regions under the NFSA.

ICDS began as an experiment aimed at nutritional assistance to pregnant and lactating mothers and children under six years of age in 1975 . In those days, child mortality in India was very high, while health and community-based systems were hardly present. Mid-term appraisal of the 11 th 5-year plan (2007-12) pointed to serious underperformance of the ICDS and its ineffectiveness in reducing undernutrition among children. ICDS was criticized for its poor design and implementation. During the last decade, however, ICDS has remarkably improved its performance driven by advocacy efforts by civil society coalitions calling for "nutrition to be a priority on the national agenda" (Balarajan \& Reich, 2016). Advocacy by civil society groups along with active interventions by the Supreme Court of India brought about significant changes in the ICDS design and implementation. Coverage of ICDS was expanded, provisions were made universal from a targeted one, and the provision of hot cooked meals was introduced. Concerns about ICDS however still exist which include inadequate infrastructure, issues of unskilled and underpaid staff and political will for its implementation (N. Rao \& Kaul, 2018). 
Political will and therefore ICDS performance again vary by states. Relatively limited focus only on children between 0 and 3 years of age has also been questioned (Drèze \& Khera, 2017).

While ICDS was designed to address the issue of early childhood development and maternal nutrition supplementation, the MDMS is a school feeding program which aimed at increasing enrolment and reducing "classroom hunger" among primary school students. MDMS is the biggest school lunch program in the world (Khera, 2006). It was introduced in 1995 as the "National Programme for Nutritional Support for Primary Education". MDMS wasn't much of a success until 2001 when its coverage was expanded to all the states of India. In the initial phase, not all schools had the right infrastructure in place to provide "cooked meals", and "dry ration" was mostly distributed. Since 2001, active intervention by the Supreme Court of India and local civil society organizations have led to mandatory provisions of cooked meals to all primary school children. MDMS now provides meals consisting of 300 calories and 8-12 grams of protein daily to all the children attending primary schools.

MDMS, as it was conceived, did manage to increase school enrolment rates; however its impact on child nutrition has been a concern as food supplementation and its quality was low. Initially, MDMS suffered from the availability of infrastructure and financial resources. With improvements in those aspects, concerns now exist around the quality of nutrition supplementations. Nutrient content of the school meals is low in comparison to the daily requirements for protein, fat, iron and other micronutrients. Often these schemes become a tool for promoting a sectarian agenda, such as the prohibition of eggs from the meals. Some states have banned eggs under MDMS, promoting vegetarianism. ${ }^{4}$ By depriving essential nutrients at early stages of life, politicians take to propagating cultural and religious dogmatism. The other issues which require immediate attention to make MDMS more effective is adequate infrastructure at schools, sufficient and trained staff, better nutrient composition of the food and adequate accountability mechanisms in place (Khera, 2013). There are also glaring food safety concerns as MDMS has often been in the news related to issues of hygiene with some cases leading to deaths. ${ }^{5}$

${ }^{4}$ http://www.huffingtonpost.in/2015/06/02/how-politics-and-religious-dogma-denyeggs-to-indias-severely-m/

${ }^{5}$ http://www.bbc.com/news/world-asia-india-23342003 


\subsubsection{Impact of Food-based Safety Net Programs on Nutrition}

Evidence of the effects of these food-based safety nets on nutrition in India remains unclear (Pingali \& Rao, 2016). It is limited by lack of availability of longitudinal data, choice of metrics for evaluating their impact, the appropriate period for analysis and the different geographical contexts. As a measure of nutrition, studies have mostly focused on the intermediated indicators of nutrition such as food intake and dietary diversity. The impact of food safety nets could be divided into two periods-before and after 2005 when these programs were revived by the government. Studies which used data before 2005 find no effect of PDS on nutrition (Kaushal \& Muchomba, 2015; Kochar, 2005; Tarozzi, 2005). Recent empirical studies, however, do provide evidence of a positive effect of PDS, on nutrient intake as well as dietary diversity (Kishore \& Chakrabarti, 2015; Krishnamurthy, Pathania, \& Tandon, 2017; Rahman, 2016). Similarly, reforms in the functioning of ICDS have led to a significant impact in reducing malnutrition. Jain (2015) finds that children receiving supplementary meals are taller compared to others - the effect being significantly higher for the girl child. Even in eastern states of India, where governance and performance of safety nets are reportedly poor (ibid), Mittal and Meenakshi (2015) find a decline in the prevalence of undernutrition among children who benefited from ICDS. MDMS, too, has had a positive impact on nutrition, especially during times of economic distress. Access to MDMS increases daily intake of essential macronutrients-calories and protein-among school children (Afridi, 2010). In another study, Singh, Park, and Dercon (2013) underscore the role of MDMS as a safety net for children who faced droughts in early years of life. They find that despite economic shocks, there was an improvement in child anthropometric measures for children with access to MDMS.

\subsubsection{Calorie-based Food Assistance}

One of the reasons for the failings of food-based safety net programs in India has been its excessive focus on calorie-based supplementation. By focusing solely on the availability and access to calories, extant food policy has been proven to be a detriment to the nutritional challenge. The rising prevalence of obesity and the persistence of micronutrient deficiencies now comprise a significant share of the "triple burden of malnutrition" (Meenakshi, 2016). Calorie assistance programs, unfortunately, are not 
designed to deal with these emerging public health challenges. With surplus production and food assistance programs, we have adequate mechanisms in place to ensure that households have sufficient food to eat; however, ensuring food security may not translate into better nutrition. India's food policy has missed this nuanced aspect of nutrition. From the perspective of human rights and ethics, the recognition of the right to food and enactment of NFSA has its heart at the right place, but it fails to consider the imperatives of a dynamic food system, which reflects changing consumption preferences and nutritional needs (de Brauw \& Suryanarayana, 2015). By explicitly focusing on a minimum calorie adequacy idea, NFSA neglects crucial aspects of nutritional security such as dietary diversity and hidden hunger due to micronutrient deficiency. This leads to a pressing question-how should we design our food assistance programs to address malnutrition in its multiple dimensions?

\subsection{Non-FOOd-BASEd SAFETy Nets}

Along with the food-based safety nets and employment guarantee schemes in rural areas, MGNREGS provides the basic existing architecture to India's social welfare regime. MGNREGS is a national-level public works program, on the lines of the Maharashtra Employment Guarantee Act of 1977. Under the MGNREGS, all adults in a rural household are guaranteed 100 days of unskilled manual work. MGNREGS is the largest social security scheme in the world which entitles the citizens to "right to work", and hence it is obligatory upon the government to provide work when demanded. The benefits of public works program as a safety net lies in the aspects of self-selection and creation of durable assets. Those who demand work are engaged in building durable assets like roads, canals, ponds and wells across rural India. This would address the issues of rural livelihood as well as infrastructure at the same time. Under the scheme, a minimum wage-material ratio of 60:40 is to be maintained. ${ }^{6}$ MGNREGS was envisaged as a program to generate employment as well as create "durable assets" which would help agriculture through creating rural infrastructure. Its performance in creating assets despite incurring high costs has led critics to refer to it as "doles for creating holes". On the operational side of it, MGNREGS, like other safety net programs also suffers from inefficiencies

\footnotetext{
${ }^{6}$ Wage here represents the amount in total paid as wages to the workers. The rest is the amount spent on materials for the public works program.
} 
such as corruption, delayed payment or lower wages to workers as a result of local political coalitions, for example, between post office officials and panchayat members, which often goes unnoticed. ${ }^{7}$

However, income earned from MGNREGS has proved to be nutrition enhancing. Using a panel data on households, Ravi and Engler (2015) find that participation in MGNREGS had a significant impact in increasing food expenditures and a significant reduction in the number of meals foregone by households. Similarly, Liu and Deininger (2010) find a positive impact of MGNREGS on consumption expenditure, asset accumulation as well as nutrient intake: calorie and protein. Wages play an important role in the income pathway to nutrition. A study by Azam (2012) shows how MGNREGS had a positive effect on agricultural wages. Contributing to the human capital, participation in the MGNREGS by women had a positive effect on the educational outcomes of children (Afridi, Mukhopadhyay, \& Sahoo, 2016).

\subsection{Political Economy of the Safety Net}

Safety nets, which Indian policymakers have designed and we discuss here can be classified as benefits which help in "consumption smoothing" rather than "mean shifting", thereby addressing vulnerability to poverty rather than its chronic manifestation (Devereux, 2002). Chronic poverty is addressed if there is an increase in factor productivity (of labor, land and capital). How much India's current and emerging safety net architecture would be able to address factor productivity is the policy question. Programs like PDS, ICDS, MDMS or pension schemes are relevant for reducing vulnerability especially to kids and elderly who cannot generate independent livelihoods of their own. Programs focused on kids have larger implications for human capital and future productivity. Public works and food assistance programs, therefore, have been more hotly contested regarding their design to achieve the desired outcome.

Part of the problem lies in the fact that safety nets are enmeshed in political incentives which inhibit reforms in the program design. PDS reforms are essentially linked to the government's farm support policies. Rice and wheat provided through PDS are procured through a system of pre-announced minimum support prices (MSP) which ensures a remunerative price to

${ }^{7}$ MGNREGS payments are made through post offices, and the panchayat leader is the sanctioning authority as the scheme is decentralized to the lowest tier of government administration. 
farmers. Initial expansion of PDS during the 1970s largely leveraged on the productivity growth that resulted from Green Revolution technologies. To promote agricultural production, the government incentivized food production through minimum support price (MSP) and amassed massive amounts of grain. These food grains found an outlet through PDS into the hands of poor consumers. Agricultural growth in the Indo-Gangetic plains-which benefited from the Green Revolution-led to a powerful political lobby of agriculturists whose interests are aligned with greater farm procurement of staple grains, which were distributed through the PDS. The interlocked farmer-consumer incentive system has made it politically challenging to introduce reforms in the PDS. While supporting agriculture makes for sound economics and politics, the procurementstocking-distribution model in the food system has led to perverse incentives for the farmers. Procurement through MSP mainly takes place for rice and wheat, which disincentivizes the production of other crops. Evidence suggest that rice-wheat dominance has led to the displacement of traditionally grown nutritious crops like coarse cereals and pulses. Such lopsided agricultural production patterns not only affect variety and essential nutrients in the food system but also undermine biodiversity.

It has been widely established that the increase in expenditure on safety nets of late has been attributed to the greater role of state governments primarily driven by three factors: history of political legacy, social coalitions and resultant political party competition, and political leaders' influence in strengthening state capacity for program delivery (Deshpande, Kailash, \& Tillin, 2017). Since the 1990s, there has been a greater role of the regional parties in central politics enabling the state governments to have a greater say in the policy space (Kennedy, 2017). The role of politics in enabling a more egalitarian and better designed safety nets in the southern states of India has been there for long, but sub-national politics has gained greater traction of late. For example, while policy legacies could explain improved safety nets in southern states of India like Kerala and Tamil Nadu, reforms in Odisha and Chhattisgarh are a result of political populism espousing egalitarian concerns of the state party leaders. Greater influence of regional political settlements and their influence over safety nets could be a function of the demands of democracy and electoral accountability. The influence of electoral politics on the design of the safety nets cannot be denied. Negotiating the needs of an evolving food system in the political space is something food policy has always grappled with. Policy interventions which focus on nutrition may be considered less attractive to gain electoral patronage, while direct food 
assistance, which is more tangible and more immediate, benefits the voters. Moving the focus to nutritional improvements - the distal outcome of food assistance-hence gets ignored. The consumer interests, therefore, get more enmeshed with the producer incentives. Innovations in food delivery mechanisms are becoming a more distant proposition.

\subsection{The Possible Future of Safety Nets in India}

Regardless of these challenges, it is an accepted fact that safety nets have been instrumental in alleviating poverty and improving the lives of millions across the world, and they will be a critical tool to fight poverty and better developmental outcomes in India too.

\subsubsection{Citizenship Rights or Hand-Outs?}

Envisaging the future of safety nets in India needs a reflection on the genesis of these programs and the recent reforms. There are two paradigms of social protection-citizenship and charity (Kidd, 2017). Under the citizenship paradigm, redistribution is considered as a public good and governments invest heavily in safety nets. The charity paradigm, however, looks to support the poor with hand-outs and has relatively lower spending on the social assistance programs. The developed world follows the citizenship paradigm, while lower developed countries follow the charity paradigm. With the strengthening of democracy and economic growth, even the low and middle-income countries like India are moving towards a citizenship paradigm based safety net, which gives the citizen a sense of entitlement (Daigneault, 2014).

India's safety net paradigm-based upon rights-based approachexhibits a similar pattern. The language of social citizenship rights through safety nets also reduces the likelihood of class-based conflict (Jayal, 2013). There could be multiple other hypotheses for India to move towards a citizenship-based paradigm of safety nets (Kapur \& Nangia, 2015). Theories of "social citizenship" in democracies initially entail civil rights (such as freedom of speech, faith and others), gradually moving to political rights, and finally the social rights which is the driver of welfare state expansion. The "compensation hypothesis" of Karl Polanyi states that expansion of welfare state takes place as economic insecurities increase with the spread of the free market and economic integration across countries as a result of globalization. The third hypothesis emerges from the 
power resources theory, according to which emergence of welfare regimes reflect class-related distribution and strengthening of partisan politics as reflected in organized demand by labor and other disadvantaged groups for protection. These hypotheses, however, are merely suggestive of the possible factors behind the emerging social welfare narrative in India with no conclusive evidence ( $i b i d$ ). Regardless of the exact motivation, it cannot be denied that the current safety net architecture in India is a combination of democratic needs, competitive politics, rising economic insecurity and genuine concerns for the poor. More importantly, safety nets in the country is going to stay, and expand further. The direction and design of the same is the issue of debate.

\subsubsection{Newer Forms of Safety Nets: Health Insurance}

With the right to food and work formally enshrined in the country's constitution, health insurance under the larger ambit of the Ayushman Bharat program is now emerging as the newer form of safety net, albeit partly private sector based, as a departure from the current solely publicly financed programs. In the 2018 budget, the government of India launched a new National Health Protection Scheme (NHPS) aiming to cover almost half of the population with a yearly family insurance cover of Rs. 5 lakhs. The antecedent of NHPS was the Rashtriya Swasthya Bima Yojana (RSBY), a health insurance program targeted specifically at the families falling below the poverty line, introduced in 2008. Under RSBY, beneficiaries (five members of the family which includes the head of household, spouse and up to three dependents) are entitled to hospitalization coverage up to Rs. 30,000 (roughly equivalent to 500 USD) for illnesses which require hospitalization. RSBY is implemented through insurance companies and provides the beneficiaries an option of choosing between public and private hospitals. Insurance premium subsidies (Rs. 750 equivalent to 12 USD annually) are shared by the Union and State governments on a 3:1 basis. The beneficiary pays a sum of Rs. 30 (0.5 USD) every year as a registration/renewal fee. State governments have introduced their versions of health insurance programs like Yeshasvini in Karnataka and Aarogyasri in Andhra Pradesh. NHPS fundamentally differs from RSBY in the sense that the former is an entitlement; all eligible households are covered once the scheme is operationalized. NHPS is a part of the Ayushman Bharat-healthy and prosperous India - a program which also includes setting up of 1.5 lakh healthcare centers. These centers would provide for comprehensive healthcare facilities 
for maternal and child health services in addition to non-communicable diseases, free essential drugs and diagnostic services. The overarching objective of this enhances productivity and well-being and enables a supporting platform for unanticipated wage loss and impoverishment.

Health insurance is a necessary inclusion to the set of safety nets in India since health shocks are one of the major causes of households falling into poverty in India (Krishna, 2011). In contrast to other safety nets which attempt to bring households out of poverty, subsidized health insurance schemes are useful protection against catastrophic health expenditures and hence lower the probability of falling into poverty.

\subsubsection{Stage of Structural Transformation and Urbanization of Safety Nets}

Urban population is expected to increase. While urban poverty in India is relatively lower than rural poverty, greater urban population increase in the future would lead to "urbanization of poverty" (Ravallion, 2002). Urban poverty has its peculiar features which include income volatility, informality in jobs and living conditions, poor social services and less cohesive community and social networks (Gentilini, 2015). The urban poor often live in locations with the poor quality of hygiene and exposure to infectious disease environment. Given a robust link between access to clean water and sanitation facilities with nutrition, the urban poor are at high levels of risk of malnutrition. Lack of adequate social protection schemes in urban areas further compound these problems. Urban residents, being net consumers of food, are also more exposed to fluctuations in prices. Informality and a high degree of inequality have been a feature of India's urbanization which makes urban poor highly vulnerable in the absence of appropriate social support programs (Roy, 2009).

In the future, the role of urban safety nets would further increase in importance. Currently, safety nets have a greater rural presence. Increase in the rate of urban poverty and the associated nutritional impacts have often been overlooked in the policy space. While poverty may not be directly related to food or nutritional security, there is a definite link between the two (Maitra \& Rao, 2015). Safety nets also need to be attuned to the greater rates of future migration to urban areas. Currently, the entitlement of migrants to the various social security benefits which are not easily transferable which inhibits inter-state labor mobility and hence structural transformation (Kone, Liu, Mattoo, Ozden, \& Sharma, 2016). 


\subsubsection{The Question of Cash Transfers}

Should safety nets should be replaced with cash transfers or Direct Benefit Transfer (DBT), as referred to in India, in place of in-kind subsidies? This question has generated a lot of academic as well policy debates in the recent past. DBT in the form of pensions - for elderly, widows and disabled-and MGNREGA payment has attained reasonable success in some states of India. The debate has largely been around PDS. Cash transfers with a lower transaction cost have been proposed as an alternative to the costly and inefficient PDS. Cash, in the hands of beneficiaries, also enables them the choice of their consumption basket. One can argue that PDS is essentially a cash transfer because the marginal propensity of cereal consumption from the PDS subsidy is close to zero (Balasubramanian, 2015). The case for cash transfers is further strengthened by a randomized controlled experiment by Gangopadhyay, Lensink, and Yadav (2015) in Delhi where they find that replacing in-kind food subsidy with cash transfers of equivalent amount does not affect food security. Khera (2014) questions gross generalization of such findings and argues that "one-size-fits-all" approach may not work, given wide regional variation in governance, infrastructure and poverty levels.

There have been multiple arguments in-kind transfers to continue. In India, where poverty levels are high and there is widespread inequality, underdeveloped credit and factor markets, paternalism being a cultural norm, "leaving people to their own devices" through cash transfers may not be a smart policy if the idea is to ensure sufficient protection against food insecurity. Khera (2014) finds that poorer households prefer cash when the PDS works poorly; however, in-kind transfers are preferred when PDS is effective. Consumer preferences also differ by gender. Women are more averse towards cash transfer programs because of restricted physical mobility and challenges of handling official banking procedures ( ibid). While these are cultural factors, critics of cash transfers have also argued that cash could be diverted into other non-food expenditures. Intra-household resource allocation depends upon patriarchal norms which could lower food access for women and children, undermining overall nutrition. The other important thing to note is the potential benefit of moving to a cash transfer when in-kind transfers have a similar effect on food consumption. Shrinivas, Baylis, Crost, and Pingali (2018) show that almost $83 \%$ of the PDS subsidy is spent on food. They also provide suggestive evidence that PDS could have a higher effect on the consumption of nutritious food than an income increase of equivalent amount. 
The success of cash transfers critically relies upon the availability of local markets. Most poor in India live in remote parts and their market accessibility is limited and raises concerns of local food availability in the absence of PDS. Cash transfers require other financial infrastructures such as the presence of banks and post offices. India lacks such rural infrastructure, without which a sudden move towards cash could increase distress, at least in the short term. Open market prices exhibit cyclic fluctuations. If cash transfers are not indexed to inflation, the benefits are likely to be eroded. While price indexation may seem a trivial exercise, its operationalization against local price increase, and the awareness among beneficiaries of their entitlement every month is often much discussed.

A significant concern when moving towards a DBT is what does the government do with the huge amount of food grains which the government procures from the farmers to incentivize production? Without an in-kind transfer through PDS, food procurement would only lead to further increase in the enormous quantities of rice and wheat which India already has a huge stock lying in its godowns. This is a major political economy question which is often not raised while discussing the move to cash transfers. Some proponents have mentioned disbanding food procurement completely, but the policy direction seems contrary to that. The last few years have seen greater food procurement than earlier. The political rhetoric of the time has seen multiple more incentives for the farmer to sell rice and wheat to the government as evident through cases in Madhya Pradesh, Chhattisgarh, Bihar, Uttar Pradesh and Odisha. Government has provided mixed signals on this issue. While it has opened up a discussion around moving towards DBT, it has been encouraging food procurement too.

\subsubsection{Universal Basic Income}

Given the difficult economics of the safety nets, global interest in the idea of a Universal Basic Income (UBI) has reached Indian shores too. Narratives around replacing the existing safety nets with a UBI have emerged as one of the most engaging debates in recent times. While academics have been talking about it for some time, Economic Survey in 2017 introduces its possibility in the policy debate by considering UBI as "... a powerful idea whose time even if not ripe for implementation is ripe for serious discussion". The survey talks about the potentials of UBI centered on the ideals of "universality, unconditionality, and agency" to "wipe[ing] every tear from every eye". Arvind Subramanian, who is 
credited with the Economic Survey, is reported to have said that UBI could be leveraged for the "liberation of the cognitive bandwidth" through the provision of a basic minimum level of assistance to the neediest. ${ }^{8}$ While the idea of UBI is appealing because it provides freedom-of choosing suitable work and consuming items of choice-operationalizing the same could be a mammoth challenge. The government hopes to leverage the advancements in technology to make this a possibility. The central government has set up the Unique Identification Authority of India (UIDAI) which collects and maintains a database on biometric and demographic identifiers of all residents and issues a 12-digit unique identity number called Aadhaar. ${ }^{9}$ Clubbing Aadhaar with the financial inclusion program, known as the Jan-Dhan Yojana, under which every citizen would have a bank account, and the expansion of the coverage of mobile phones-popularly called JAM (Jan Dhan-Aadhaar-Mobile) trinity-the government aims to build up a technology-based architecture to make this a reality.

\subsubsection{Use of Technology for Efficient Safety Nets}

Advancements in the information and communication technologies (ICTs) have definitely revolutionized the flow and timeliness of information across multiple nodes and hence offer a brilliant option to curb leakages and local elite capture-often attributed to poor performance-in the implementation of safety nets. ICT could ensure accountability between the policymakers, service providers, and citizens. JAM trinity is expected to be a game changer regarding how social security programs operate in India. By linking Aadhaar (biometric identification) of the beneficiaries with their Jan Dhan bank accounts and mobile phones, funds could be directly transferred to the beneficiaries into their bank accounts. This cuts out the intermediaries in the citizen-state interactions. According to the Economic Survey, this would save around about Rs. 3.78 lakh crore (6,000 billion USD) or 4.2\% of India's GDP, which is currently spent on key subsidies. ${ }^{10}$ While the idea is compelling and is something which the government is seriously considering, ground-level realities produce a sobering picture of the usefulness of

${ }^{8}$ https://www.cgdev.org/blog/reducing-poverty-india-with-power-digital-payments-UBI

${ }^{9}$ Aadhaar is the world's largest national identification number project.

${ }^{10}$ The estimate also includes subsidies on fertilizers, LPG and other items which are not discussed here. 
ICT, at least for now. It has often been found that the biometrics of many beneficiaries, especially among the poorest of the population, is not easily registered on the scanning devices. Lack of electricity and banking infrastructure in some of the remote parts of the country make it cumbersome for the people to access benefits. On account of technological glitches, wage payments are often delayed, irregular or even rejected at times.

Robust ICT systems take time and the required infrastructure needs sophistication and appropriate database security systems. While ICT is increasingly being used for program delivery and effectively so in many places, when would be the right time for India to introduce a cash transfer scheme or UBI, leveraging the available technology and identification system, only time would tell.

\subsubsection{Linkage and Synergies with Agriculture}

Critics of the narrowly targeted programs have argued that often the entitlements are mere "...token handouts to make harsh neo-liberal reforms politically palatable, or to avoid taking real actions to redress the structural causes of poverty and vulnerability" (Devereux, 2002). They highlight the fact that market-based reforms in the developing world left many behind increasing inequality. Social security benefits in some way ameliorate those impacts for the poor. These necessary interventions do not address the structural roots of poverty. We would like to argue that greater investment in agriculture - private and public — and the right incentives for producers should be the way ahead.

A major share of India's population lives in rural areas and is primarily engaged in agriculture-based livelihoods. For India's nutritional security, the challenge lies in ensuring that social security interventions are effective at scale, which requires coordinated investments across sectors to address deep-rooted causes of malnutrition (Kadiyala, Joshi, Mahendra Dev, Nandakumar, \& Vyas, 2012). Agriculture as the central focus of tackling nutrition has been widely recognized in the academic as well as policy circles (Tirivayi, Knowles, \& Davis, 2016). Safety nets, food insecurity and poverty, and agriculture are inextricably linked in the rural economy, and these synergies make for a more resilient food system. Safety nets could be used to increase productive investments in agriculture leading to overall economic growth through multiple pathways (Hoddinott, 2008). First, safety nets help in generating household assets. Second, they also protect against assets when during times of economic shocks. Third, acting as a 
risk coping mechanism, they allow households to use their existing resources better. Fourth, by supporting the poor, safety nets contribute to a reduction in inequality and promote growth.

The agricultural sector has been found to more effective in reducing extreme poverty, while the non-agricultural sector has been proven more beneficial in reducing less severe poverty (Christiaensen, Demery, \& Kuhl, 2011 ). Hence, pro-poor policies call for greater investments in agricultural development. Examining trends in poverty and nutrition for 29 countries during the period of economic transformation, Webb and Block (2012) find that the structural transformation leads to increase in total income and poverty reduction faster if there is strong support for agriculture. Reduction in poverty, in turn, leads to better nutrition, especially in rural areas. This transformation, however, brings with it the risks associated with the greater prevalence of obesity and non-communicable chronic diseases. Hence, to avoid these negative consequences, the transition needs careful management through a suitable design of support for smallholder agriculture along with the appropriate health interventions. Existing evidence from Latin America and Africa suggests so. In Latin America, conditional cash transfers have proved to be beneficial in increasing land use, farm implements and livestock ownership. Similarly, in Africa, cash transfer programs have led to greater input use and productive investments in agriculture.

There are enough avenues for greater synergies between the safety net programs and agriculture in India. Rural asset creation through MGNREGS could be leveraged to revitalize agriculture. Rain-fed agriculture, where irrigation facilities are fewer, could be suitable to grow coarse grains and pulses, which could be provided through the PDS. It would be a useful step towards the larger goal of nutritional security with more diversified diets as well as production systems. Food can be produced locally for MDMS, ICDS or PDS, which would not only boost the local economy but would also adhere to the local tastes.

\subsubsection{Government Investment in Public Goods}

According to the FAO (2015), reliance on social protection alone to address hunger and rural poverty would be a flaw. Safety nets need to be combined with sufficient public and private investments in agriculture along with rural developmental programs to ensure inclusive and sustainable economic growth in addressing the cycle of rural poverty. Illustrations 
from across the globe also throw up a contrasting result. While countries in East Asia, the Pacific and Southeast Asia have been able to reduce the prevalence of hunger and poverty successfully through safety nets, South Asia and sub-Saharan Africa have shown much slower progress. Social safety nets are crucial for smoothening consumption across the year, avoiding the sale of assets or retaining children in school during times of economic distress. However, other important interventions, such as irrigation, markets, rural infrastructure, promoting agricultural extension services, and facilities for crop and weather insurance play a huge role in reducing the vulnerability of farmers. Some of these programs are not very lucrative from the point of politicians as they do not bring in immediate gains and are less populist.

One must understand that emergence of the social safety architecture in the last two decades is associated with some of the major macrotransformations in the Indian economy as well as a polity. First, the greater intensity of electoral competition has led the emergence of newer political settlements across various interest groups with clearer identification of constituencies and the desired push towards gaining their electoral support. Second, economic growth since the 1990s has increased the government's fiscal capacity to finance greater investment on safety nets. Third, the fiscal capacity has increased, the government's administrative capacity, especially at the local level may have weakened which has led to worsening of the quality of public goods such as schools and hospitals. Safety nets become more alluring to the voters, especially when the quality of public services is on the wane. Elected representatives, on the other hand, use these transfers as an incentive to bypass issues around poor provisioning of public infrastructure.

While India has been effectively trying to weave in a safety net for the poor, the provision of essential public amenities or public goods such as access to clean water, sanitation, electricity, roads and so on hasn't got the desired attention. Kapur and Nangia (2015) attribute this to the government's weak administrative capacity. They argue that by prioritizing safety nets over the creation of durable public goods, India has taken the path followed by many of the Latin American countries, which took to social security spending as a way to reduce poverty. Comparative analysis, however, suggests that in the long run welfare outcomes were better among the East Asian countries which spent more on creating better provisioning of public infrastructure while being a minimalist welfare state. 
Nutrition as a public good, too, has never been a priority development agenda until very recent times. Recent improvements in the performance of food-based safety can be attributed to strong advocacy groups and judicial activism in the country which necessitated state intervention. The realization that economic growth is no panacea to improved nutrition and the basic human right of food entitlement has been the bedrock of this movement. This led to powerful rights-based movement championed by the "right to food" initiative which has brought about much expediency to the policy (Gillespie, Haddad, Mannar, Menon, \& Nisbett, 2013). Judicial interventions by the Supreme Court of India helped advance the right to food of specific food-deprived populations and significantly contributed to reducing hunger. This was also helped by the center-left alliance which supported the cause of social welfare programs with the expansion and universalization of many of these schemes (Balarajan \& Reich, 2016).

\subsection{Conclusion}

The current set of safety nets in India-ICDS, MGNREGA, PDS and MDMS - provide income and nutritional assistance during different stages of the life cycle of an individual. The essential idea behind these interventions is to enhance individual capabilities and welfare through more equitable access to food and income. Individual capabilities are increased through a reduction in malnutrition, improved labor productivity, better human capital and reduction in overall inequality of opportunity. It has taken almost 70 years since independence to create a basic safety net architecture, which is intrinsically linked to the economy's structural transformation. Economic growth has definitely played a role in the creation of a basic safety net platform. Improvements in the coverage of safety nets during the last 25 years have benefited from the quadrupling of public revenue which has eased out the resource barrier and made its implementation more affordable (Drèze \& Khera, 2017). On the demand side, there have been multiple reasons for this expansion. Increase in interpersonal inequality along with economic growth has led to rising demand for expansion in safety net provisions. Citizens in India are now much more empowered, and civil society plays an active role in channelizing the concerns leading to a citizenship paradigm for safety nets. Public policy towards safety nets has also been influenced by electoral concerns. Expansion and improvement in many of these safety net programs have also been influenced by the electoral arithmetic of mobilizing voter 
support leveraging upon the populistic nature of these schemes. Universalization of these schemes, rather than targeted poverty reduction interventions, suggests a rise in the support by the political elites.

Safety nets, however, have been an essential part of the poverty reduction policies contributing to risk management and vulnerability reduction for a large section of the population. While these interventions have largely been laudable, looking into the future one does need to think about their future role. These policies over time should become more transformational rather than just vulnerability reducing. Structural roots of poverty need to be addressed through combining safety nets with structural reforms and long-term interventions with the aim of increasing human capabilities and addressing structural poverty through that. Synergies between agriculture and safety nets, therefore, become essential. Public work and life-cycle-based food assistance programs need to be dovetailed into the local agrarian economy.

The future of safety nets has to take into account the changing nature of the economic structure, demographic changing and future livelihood patterns. Urbanization, especially, poses a challenge as well as opportunity in restructuring the safety net architecture. Current policies which mostly address rural poverty do not consider the fact that India would be more urban than rural by 2050 . With rising urbanization, urban informality and unemployment in urban areas, especially educated unemployment, raise important challenges for the food systems going ahead. Movement of labor from rural to urban areas is further going to increase the share of net consumers who need to be shielded away from rising food prices. Observing the nature of transition in a developed country like the United States offers useful clues. In the United States, many of the workers make a living doing multiple odd jobs comprising what they call as a part of gig economies. The Government Accountability Office classified about 31\% of the workforce in America as "contingent" workers. The rise in informality in the Indian urban sector is not very different, and it may not be a stretch to imagine the condition to be far worse in India where labor regulations are hardly effective.

The issue of safety net design also needs serious considerations. The current system does suffer from problems of corruption and leakages. ICTs could be utilized better to curb these inefficiencies. Research has shown its benefits in improving program effectiveness for MGNREGA and PDS. Identification of beneficiaries through Aadhaar has bolstered the case for cash transfers, yet it is important however to recognize the use 
they could serve without compromising identity security. Many of the loopholes exist regarding biometric authentication using Aadhaar which often becomes a hindrance rather than benefits the poor. These inefficiencies should be ironed out.

Innovations in the food-based safety nets are seriously limited by the modalities of grain procurement structure which incentivizes only staples, potentially crowding out more nutritive food products. This not only is disadvantageous for the consumers through restricting choice, but also undermines the idea of a nutrition-sensitive food production system. It is therefore essential to break the staple grain procurement-storagedistribution interlocked channel. These interlocked incentives are however deeply mired in India's rural political economy which is a major obstacle to food system diversification.

We would also like to highlight here that Indian public policy has often undermined the provision of essential public goods and services which are complimentary to safety nets. Public good provisioning has been ignored as expenditure on safety nets have got priority. The poor quality of infrastructure-urban as well rural-is a testimony to that. It has been well established that long-term welfare depends upon the quality of durable public infrastructure as reflected in the success of East Asian countries which reduced poverty despite not having a welfare state.

\section{REFERENCES}

Afridi, F. (2010). Child welfare programs and child nutrition: Evidence from a mandated school meal program in India. Journal of Development Economics, 92(2), 152-165. https://doi.org/10.1016/j.jdeveco.2009.02.002

Afridi, F., Mukhopadhyay, A., \& Sahoo, S. (2016). Female labor force participation and child education in India: Evidence from the National Rural Employment Guarantee Scheme. IZA Journal of Labor \& Development, 5(1), 7. https://doi.org/10.1186/s40175-016-0053-y

Azam, M. (2012). The impact of Indian job guarantee scheme on labor market outcomes: Evidence from a natural experiment. IZA Working Paper 6548, World Bank, pp. 1-34. https://doi.org/10.2139/ssrn.1941959

Balarajan, Y., \& Reich, M. R. (2016). Political economy of child nutrition policy: A qualitative study of India's Integrated Child Development Services (ICDS) scheme. Food Policy, 62, 88-98. https://doi.org/10.1016/j. foodpol.2016.05.001

Balasubramanian, S. (2015). Is the PDS already a cash transfer? Rethinking India's food subsidy policies. The Journal of Development Studies, 51(6), 642-659. https://doi.org/10.1080/00220388.2014.997221 
Christiaensen, L., Demery, L., \& Kuhl, J. (2011). The (evolving) role of agriculture in poverty reduction-An empirical perspective. Journal of Development Economics, 96(2), 239-254. https://doi.org/10.1016/j.jdeveco.2010.10.006

Croppenstedt, A., Knowles, M., \& Lowder, S. K. (2017). Social protection and agriculture: Introduction to the special issue. Global Food Security, 16(2), 0-1. https://doi.org/10.1016/j.gfs.2017.09.006

Daigneault, P.-M. (2014). Three paradigms of social assistance. SAGE Open, 4(4), 1-8. https://doi.org/10.1177/2158244014559020

de Brauw, A., \& Suryanarayana, M. (2015). Linkages between poverty, food security and undernutrition: Evidence from China and India. China Agricultural Economic Review, 7(4), 655-667. https://doi.org/10.1108/ CAER-09-2015-0117

Deshpande, R., Kailash, K. K., \& Tillin, L. (2017). States as laboratories: The politics of social welfare policies in India. India Review, 16(1), 85-105. https:// doi.org/10.1080/14736489.2017.1279928

Devereux, S. (2002). Can social safety nets reduce chronic poverty? Development Policy Review, 20(5), 657-675. https://doi.org/10.1017/S1464793106007007

Drèze, J., Himanshu, Khera, R., \& Sen, A. (2015). Clarification on PDS leakages. Economic and Political Weekly, 50(39), 72-73.

Drèze, J., \& Khera, R. (2017). Recent social security initiatives in India. World Development, 98, 555-572. https://doi.org/10.1016/j.worlddev.2017.05.035

FAO. (2015). Social protection and agriculture: Breaking the cycle of rural poverty. In The state of food and agriculture. Rome.

Gangopadhyay, S., Lensink, R., \& Yadav, B. (2015). Cash or In-kind transfers? Evidence from a randomised controlled trial in Delhi, India. The Journal of Development Studies, 51(6), 660-673. https://doi.org/10.1080/00220388. 2014.997219

Gentilini, U. (2015). Entering the city: Emerging evidence and practices with safety nets in urban areas.

Gillespie, S., Haddad, L., Mannar, V., Menon, P., \& Nisbett, N. (2013). The politics of reducing malnutrition: Building commitment and accelerating progress. The Lancet, 382(9891), 552-569. https://doi.org/10.1016/ S0140-6736(13)60842-9

Government of India. (2018). Economic survey 2017-2018.

Hirway, I. (2003). Identification of BPL households for poverty alleviation programmes. Economic and Political Weekly, 4803-4808.

Hoddinott, J. (2008). Social safety nets and productivity enhancing investments in agriculture. Washington, DC: IFPRI.

Jain, M. (2015). India's struggle against malnutrition-Is the ICDS program the answer? World Development, 67, 72-89. https://doi.org/10.1016/j. worlddev.2014.10.006

Jayal, N. G. (2013). Citizenship and its discontents: An Indian history. Harvard University Press. 
Jha, S., \& Ramaswami, B. (2010). How can food subsidies work better? Answers from India and the Philippines. ADB Economics Working Paper Series, 221(221), 1-35. https://doi.org/10.2139/ssrn.1721907

Kadiyala, S., Joshi, P. K., Mahendra Dev, S., Nandakumar, T., \& Vyas, V. (2012). A nutrition secure India. Economic and Political Weekly, XLVII(8), 21-25.

Kapur, D., \& Nangia, P. (2015). Social protection in India: A welfare state sans public goods? India Review, 14(1), 73-90. https://doi.org/10.1080/147364 89.2015.1001275

Kaushal, N., \& Muchomba, F. M. (2015). How consumer price subsidies affect nutrition. World Development, 74, 25-42. https://doi.org/10.1016/j. worlddev.2015.04.006

Kennedy, L. (2017). State restructuring and emerging patterns of subnational policy-making and governance in China and India. Environment and Planning C: Politics and Space, 35(1), 6-24. https://doi.org/10.1177/0263 $774 \times 16630551$

Khera, R. (2006). Mid-day meals in primary schools: Achievements and challenges. Economic and Political Weekly, 41(46), 4742-4750. Retrieved from http://www.jstor.org/stable/4418915

Khera, R. (2013). Mid-day meals: Looking ahead. Economic \& Political Weekly, 48(32), 12-14. Retrieved from http://www.righttofoodindia.org/data/ mdm/MidDay_Meals_Looking_Ahead.pdf

Khera, R. (2014). Cash vs. in-kind transfers: Indian data meets theory. Food Policy, 46, 116-128. https://doi.org/10.1016/j.foodpol.2014.03.009

Kidd, S. (2017). Citizenship or charity: The two paradigms of social protection.

Kishore, A., \& Chakrabarti, S. (2015). Is more inclusive more effective? The 'New Style' public distribution system in India. Food Policy, 55, 117-130. https:// doi.org/10.1016/j.foodpol.2015.06.006

Kochar, A. (2005). Can targeted food programs improve nutrition? An empirical analysis of India's public distribution system. Economic Development and Cultural Change, 54(1), 203-235. https://doi.org/10.1086/431260

Kone, Z. L., Liu, M. Y., Mattoo, A., Ozden, C., \& Sharma, S. (2016). Internal borders and migration in India. Policy Research Working Paper No. 8244.

Kotwal, A., \& Ramaswami, B. (2014, September). Delivering food subsidy: The state and the market. In The Oxford handbook of food, politics, and society (pp. 301-326). Oxford University Press.

Krishna, A. (2011). One illness away: Why people become poor and how they escape poverty. Oxford University Press.

Krishnamurthy, P., Pathania, V., \& Tandon, S. (2017). Food price subsidies and nutrition: Evidence from state reforms to India's public distribution system. Economic Development and Cultural Change, 66(1), 55-90. https://doi. org/10.1086/694033

Liu, Y., \& Deininger, K. (2010). Poverty impacts of India's national rural employment guarantee scheme: Evidence from Andhra Pradesh. 
Maitra, C., \& Rao, D. S. P. (2015). Poverty-food security nexus: Evidence from a survey of urban slum dwellers in Kolkata. World Development, 72, 308-325. https://doi.org/10.1016/j.worlddev.2015.03.006

Meenakshi, J. V. (2016). Trends and patterns in the triple burden of malnutrition in India. Agricultural Economics, 47(S1), 115-134. https://doi.org/10.1111/ agec. 12304

Mittal, N., \& Meenakshi, J. V. (2015). Utilization of ICDS services and their impact on child health outcomes: Evidence from three East Indian states. New Delhi.

Narayanan, S., \& Gerber, N. (2017). Social safety nets for food and nutrition security in India. Global Food Security, 15, 65-76. https://doi.org/10.1016/j. gfs.2017.05.001

Panda, S. (2015). Political connections and elite capture in a poverty alleviation programme in India. The Journal of Development Studies, 51(1), 50-65. https://doi.org/10.1080/00220388.2014.947281

Pingali, P., \& Rao, T. (2016). Understanding the multidimensional nature of the malnutrition problem in India. In P. Pingali \& G. Feder (Eds.), Agriculture and rural development in a globalizing world. Routledge.

Rahman, A. (2016). Universal food security program and nutritional intake: Evidence from the hunger prone KBK districts in Odisha. Food Policy, 63, 73-86. https://doi.org/10.1016/j.foodpol.2016.07.003

Rao, N., \& Kaul, V. (2018). India's integrated child development services scheme: Challenges for scaling up. Child: Care, Health and Development, 44(1), 31-40. https://doi.org/10.1111/cch.12531

Ravallion, M. (2002). On the urbanization of poverty. Journal of Development Economics, 68(2),435-442.https://doi.org/10.1016/S0304-3878(02)00021-4

Ravi, S., \& Engler, M. (2015). Workfare as an effective way to fight poverty: The case of India's NREGS. World Development, 67, 57-71. https://doi. org/10.1016/j.worlddev.2014.09.029

Roy, A. (2009). Why India cannot plan its cities: Informality, insurgence and the idiom of urbanization. Planning Theory, 8(1), 76-87. https://doi. org/10.1177/1473095208099299

Shrinivas, A., Baylis, K., Crost, B., \& Pingali, P. (2018). Do staple food subsidies improve nutrition? Unpublished manuscript. Retrieved from http://barrett. dyson.cornell.edu/NEUDC/paper_520.pdf

Singh, A., Park, A., \& Dercon, S. (2013). School meals as a safety net: An evaluation of the midday meal scheme in India. Economic Development and Cultural Change, 62(2), 275-306.

Tarozzi, A. (2005). The Indian public distribution system as provider of food security: Evidence from child nutrition in Andhra Pradesh. European Economic Review, 49(5), 1305-1330. https://doi.org/10.1016/j.euroecorev.2003.08.015 
Tirivayi, N., Knowles, M., \& Davis, B. (2016). The interaction between social protection and agriculture: A review of evidence. Global Food Security, 10, 52-62. https://doi.org/10.1016/j.gfs.2016.08.004

Webb, P., \& Block, S. (2012). Support for agriculture during economic transformation: Impacts on poverty and undernutrition. Proceedings of the National Academy of Sciences, 109(31), 12309-12314. https://doi.org/10.1073/ pnas. 0913334108

Open Access This chapter is licensed under the terms of the Creative Commons Attribution 4.0 International License (http://creativecommons.org/licenses/ by $/ 4.0 /$ ), which permits use, sharing, adaptation, distribution and reproduction in any medium or format, as long as you give appropriate credit to the original author(s) and the source, provide a link to the Creative Commons licence and indicate if changes were made.

The images or other third party material in this chapter are included in the chapter's Creative Commons licence, unless indicated otherwise in a credit line to the material. If material is not included in the chapter's Creative Commons licence and your intended use is not permitted by statutory regulation or exceeds the permitted use, you will need to obtain permission directly from the copyright holder.

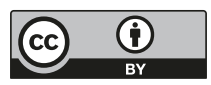

